\title{
ADRB2 GENE POLYMORPHISMS AND SALBUTAMOL RESPONSIVENESS IN SERBIAN CHILDREN WITH ASTHMA
}

Jovicic $\mathrm{N}^{1, *}$, Babic $\mathrm{T}^{2}$, Dragicevic $\mathrm{S}^{2}$, Nestorovic $\mathrm{B}^{1,3}$, Nikolic $\mathrm{A}^{2}$

*Corresponding Author: Dr. Nevena Jovicic, Department of Pulmonology and Allergology, University Children's Hospital, Tirsova 10, 11000 Belgrade, Serbia. Tel: +38-164-115-6721. Fax:+38-111-268-5378. E-mail: jovicic.nevena@gmail.com

\begin{abstract}
Inhaled $\beta 2$ adrenergic receptor ( $\beta 2-\mathrm{AR})$ agonists are the mainstay of asthma therapy. The $\beta 2-\mathrm{AR}$ protein is encoded by the $A D R B 2$ gene and variants within this gene can have significant consequences for modulating the response to asthma therapy. This cross-sectional study performed at the University Children's Hospital in Belgrade, included 54 children with asthma. The subjects were genotyped for ADRB2 +46A $>$ G (Arg16Gly, rs1042713) and +79C $>$ G (Gln27Glu, rs 1042714) polymorphisms and the association with asthma severity and response to inhaled salbutamol was examined. In Serbian asthmatic children, allele $+46 \mathrm{~A}$ was detected with a frequency of $41.7 \%$ and allele $+79 \mathrm{G}$ was detected with a frequency of $23.1 \%$. Allele $+46 \mathrm{G}$ was found to be associated with a better response to inhaled salbutamol $(p<0.05)$ and with mild form of asthma $(p<0.05)$. Polymorphism ADRB2 $+46 \mathrm{~A}>\mathrm{G}$ may be a determinant of asthma severity and response to salbutamol in children with asthma. We did not find any association of $+79 \mathrm{C}>\mathrm{G}$ polymorphisms with the asthma severity and bronchodilator response to inhaled salbutamol. The results of this study can be potentially useful for personalization of asthma treatment.

Keywords: $A D R B 2$ gene; Asthma; Bronchodilatator response; Polymorphism.
\end{abstract}

\section{INTRODUCTION}

Inhaled $\beta 2$ adrenergic receptor ( $\beta 2-\mathrm{AR})$ agonists are drugs that form the basis of asthma therapy [1]. They are

\footnotetext{
${ }^{1}$ Department of Pulmonology and Allergology, University Children's Hospital, Belgrade, Serbia

${ }^{2}$ Laboratory for Molecular Biology, Institute of Molecular Genetics and Genetic Engineering,University of Belgrade, Belgrade, Serbia

${ }^{3}$ Faculty of Medicine, University of Belgrade, Belgrade, Serbia
}

administered periodically or continuously, and during disease exacerbations. The absence of response to the applied therapy and the occurrence of severe exacerbation of the disease requires admission to the hospital, and in the most severe cases, to the pediatric intensive care unit. Therefore, prediction of response to a specific therapy is of great importance in the treatment of asthma exacerbations in children [2].

The $\beta 2-\mathrm{AR}$ is encoded by the $A D R B 2$ gene and its variations can significantly modulate the response to asthma therapy [3]. The $A D R B 2$ gene is located on chromosome 5q31-q32, in a region associated with asthma. Several polymorphisms in the ADRB2 gene have been described [4]. The $\beta 2$ receptors are present in the respiratory tract, especially in the smooth muscle cells. The most important clinical effect of activation of $\beta 2$-AR by its agonists is relaxation of the lung smooth muscles. Chronic exposure to the agonists leads to a significant reduction in the number of $\beta 2-\mathrm{AR}$ on the surface of the cell [4].

The two most common polymorphisms in the ADRB2 gene are $+46 \mathrm{~A}>\mathrm{G}(\mathrm{Arg} 16 \mathrm{Gly}, \mathrm{rs} 1042713)$ and $+79 \mathrm{C}>\mathrm{G}$ (Gln27Glu; rs 1042714) [5]. There is evidence that $+46 \mathrm{~A}>\mathrm{G}$ and $+79 \mathrm{C}>\mathrm{G}$ polymorphisms alter the functioning of the receptor, leading to down-regulation of $\beta 2-\mathrm{AR}$ and thereby induce a resistance to the effect of $\beta 2$-agonists [6]. A significant correlation was found between the positive therapeutic response to inhaled $\beta 2$-agonists in children with asthma and +46AA genotype in comparison with $+46 \mathrm{AG}$ and $+46 \mathrm{GG}$ genotypes $[7,8]$. Polymorphism $+46 \mathrm{~A}>\mathrm{G}$ can be an important factor in the overall genetic risk of developing asthma, while polymorphism $+79 \mathrm{C}>\mathrm{G}$ is described as a risk factor for asthma in adults in some ethnic groups [9-11]. A previous study in the Serbian population has shown that adult carriers of allele $+79 \mathrm{C}$ and genotype $+79 \mathrm{CC}$ are at increased risk of developing asthma [12].

The aim of this study was to analyze the incidence of $+46 \mathrm{~A}>\mathrm{G}$ and $+79 \mathrm{C}>\mathrm{G}$ polymorphisms/variants in Serbian 
children with asthma, and to investigate their influence on the severity of the disease and the response to inhaled $\beta 2$-agonists.

\section{MATERIAL AND METHODS}

Subjects. The cross section study was conducted at the University Children's Hospital in Belgrade during the period from October 2016 to May 2017 and included 54 children of Serbian ethnicity with asthma (6-18 years old). The diagnosis of asthma and disease severity were set in accordance with the Global Initiative for Asthma (GINA) 2016 guidelines. Severity was assessed retrospectively from the level of treatment required to control symptoms and exacerbations. Subjects were classified into three subgroups: mild, moderate and severe asthma. Children with asthma who had some other illnesses that may affect lung function were excluded from the study, as well as children with any chronic disease other than asthma such as bron-chopulmonary dysplasia, tracheobronchial malacia and/or congenital heart disease. The allergic classification was defined by co-occurrence of positive prick skin tests for inhalation allergens, increased serum IgE levels, more than $4.0 \%$ eosinophils in peripheral blood in the absence of parasites (three negative stool analyzes for parasites 3 months prior to testing) and co-occurrence of atopic dermatitis as a cumulative nature and which was not present during the study period or in the previous 12 months. None of the subjects had acute exacerbation of asthma. The study was approved by the Ethics Committee of the Faculty of Medicine University of Belgrade (decision No: 29/III-30, 28/3/2016).

Detailed anamnesis, physical examination and lung function tests were performed in all subjects. Pulmonary function tests were performed using a spirometric unit (Ganshorn-Schiller SpiroJet 140091; Ganshorn Medizin Electronic GmbH, Niederlauer, Germany). Spirometry was performed according to the standards of the American Thoracic Society [13]. Spirometric measurements included forced expiratory volume in the first second (FEV1), forced vital capacity (FVC) and peak expiratory flow (PEF). The results of pulmonary function tests were expressed as a percentage of predicted values. Children with asthma received an instruction to stop the systemic bron-chodilator or corticosteroid therapy for 72 hours prior to testing, as well as the use of short-acting $\beta 2$-agonists 12 hours prior to testing. Response to a short-acting bronchodilator was assessed by applying a single dose of salbutamol ( 0.15 $\mathrm{mg} / \mathrm{kg}$ ) using the Omron Nebuliser (NE-C28P-E; Omron Healthcare Group, Kyoto, Japan), and by performing the lung function test before and $15 \mathrm{~min}$. after administration of nebulized salbutamol. The response to salbutamol was measured by recording a change in the percentage of FEV1 obtained before and after salbutamol administration [13].

Genotyping of ADRB2 +46G $>$ A and +79C $>$ G Polymorphisms/Variants. Genomic DNA was extracted from peripheral blood using PureLink Genomic DNA Mini Kit (Thermo Fisher Scientific, Waltham, MA, USA). The presence of $+46 \mathrm{~A}>\mathrm{G}$ and $+79 \mathrm{C}>\mathrm{G}$ polymorphisms/variants was determined by direct sequencing of polymerase chain reaction (PCR) products obtained with the following primers: 5'-CTG AAT GAG GCT TCC AGG CGT-3' and 5'-ACA ATC CAC ACC ATC AGA AT-3'. The PCR was conducted in a $50 \mu \mathrm{L}$ reaction mixture containing: $1 \times$ KAPA Taq Buffer A (KAPA Biosystems, Waltham, MA, USA), $0.3 \mathrm{mM} \mathrm{MgCl}, 0.2 \mathrm{mM}$ each dNTP, $10 \mathrm{pmol}$ of each primer, 2U of KAPA Taq DNA Polymerase (KAPA Biosystems) and approximately $300 \mathrm{ng}$ of DNA. The amplifications were performed as follows: initial denaturation for $5 \mathrm{~min}$. at $94{ }^{\circ} \mathrm{C} ; 35$ cycles consisting of 30 seconds at $94{ }^{\circ} \mathrm{C}, 30$ seconds at $60{ }^{\circ} \mathrm{C}$ and 30 seconds at $72{ }^{\circ} \mathrm{C}$; final extension for $10 \mathrm{~min}$. at $72{ }^{\circ} \mathrm{C}$. The obtained PCR fragments (584 bp long) were purified with PureLink PCR Purification Kit (Thermo Fisher Scientific) and sequenced using the BigDye Terminator v3.1 Cycle Sequencing Kit (Thermo Fisher Scientific) and the same primers as for the amplification. Products of sequencing reactions were analyzed by capillary electrophoresis on an ABI PRISM $®$ 3130 Genetic Analyzer (Applied Biosystems, Foster City, CA, USA), and sequencing analysis software (Applied Biosystems).

Statistical Analyses. Statistical analysis was performed using the Statistical Package for the Social Sciences (SPSS) version 20.0 (SPSS Inc., Chicago, IL, USA). Data were expressed as percentages and means \pm standard deviation (SD) for continuous variables and percentages for categorical variables. To test the normality of the parameters, one sample Kolmogorov-Smirnov test was used. Differences between groups for categorical data were tested by $\chi^{2}$ analysis, while for continuous data Independent Samples Mann-Whitney U test and the Kruskal-Wallis test were used. Hardy-Weinberg equilibrium was analyzed by the Arlequin software. A $p$ value of less than 0.05 was considered statistically significant.

\section{RESULTS}

The study included a group of 54 asthmatic children (6-18 years old, 22 girls and 32 boys), whose demographic and clinical characteristics are presented in Table 1. All asthmatic children were of a Serbian ethnic group. The 
patients were divided in accordance with GINA 2016 guidelines into three groups according to their asthmatic severity: mild, moderate and severe. There was no association of age or gender with asthma severity in this group of patients. All patients were genotyped for the $A D R B 2$ gene polymorphisms $+46 \mathrm{~A}>\mathrm{G}$ and $+79 \mathrm{C}>\mathrm{G}$ by direct DNA sequencing. Allele $+46 \mathrm{~A}$ was detected with a frequency of $41.7 \%$, while allele $+79 \mathrm{G}$ was detected with a frequency of $23.1 \%$ (Table 1 ).

Response to salbutamol (measured by recording the change in the percentage of FEV1 before and after salbutamol administration and expressed as a percentage difference in FEV1 (dFEV1) after and before salbutamol administration) and severity of the disease were compared between carriers of different ADRB2 genotypes (Table 2). There was no significant difference in response to salbutamol between boys and girls. The presence of the $+46 \mathrm{G}$ allele in the $A D R B 2$ gene correlates with better bronchodilator response to salbutamol $(p=0.044)$. This allele was also associated with a mild form of the disease $(p=0.010)$. No significant association was found between the $+79 \mathrm{C}>\mathrm{G}$ polymorphism and asthma severity $(p=0.955)$ or better bronchodilator response to salbutamol ( $p=0.316$ ). In the analysis of the $A D R B 2$ gene polymorphism distribution in respect to the clinical characteristics of asthmatic children, no significant association was found between carriers of the different genotypes (Table 2).

The distribution of observed genotypes for $+46 \mathrm{~A}>\mathrm{G}$ and $+79 \mathrm{C}>\mathrm{G}$ polymoprhisms were consistent with the Hardy-Weinberg equilibrium $(p=0.050$ and $p=0.359$,
Table 1. Demographic and clinical characteristics of patients and ADRB2 genotype distribution.

\begin{tabular}{|l|c|}
\hline Age in years (mean \pm SD) & $\mathbf{1 1 . 9} \pm \mathbf{2 . 7}$ \\
\hline Gender (\%) & $\begin{array}{l}\text { M: } 59.3 ; \\
\text { F: } 40.7\end{array}$ \\
\hline FEV1 before salbutamol (\%) (mean \pm SD) & $87.1 \pm 11.3$ \\
\hline FEV1 after salbutamol (\%) (mean \pm SD) & $98.8 \pm 9.1$ \\
\hline Asthma severity: $n(\%)$ & $23(42.6)$ \\
mild & $14(25.9)$ \\
moderate & $17(31.5)$ \\
severe & $43(79.6)$ \\
\hline Atopic dermatitis: $n(\%)$ & $143.3 \pm 49.5$ \\
\hline Serum IgE $(\mathrm{IU} / \mathrm{mL})($ mean \pm SD) & $6.3 \pm 2.1$ \\
\hline Blood eosinophils $(\%)($ mean \pm SD) & \\
\hline Allele $+46 \mathrm{~A}>\mathrm{G}: n(\%)$ & $45(41.7)$ \\
A & $63(58.3)$ \\
G & \\
\hline Allele $+79 \mathrm{C}>\mathrm{G}: n(\%)$ & $83(76.9)$ \\
C & $25(23.1)$ \\
G & $13(24.1)$ \\
\hline Genotype $+46 \mathrm{~A}>\mathrm{G}: n(\%)$ & $19(35.2)$ \\
AA & $22(40.7)$ \\
GA & \\
GG & $34(63.0)$ \\
\hline Genotype $+79 \mathrm{C}>$ G: $n(\%)$ & $15(27.8)$ \\
CC & $5(9.2)$ \\
CG & \\
GG & \\
\hline
\end{tabular}

SD: standard deviation; M: males; F: females;

FEV1: forced expiratory volume in the first second.

respectively). The three allele combinations were identified in our group of patients: $+46 \mathrm{~A} /+79 \mathrm{C}(41.7 \%),+46 \mathrm{G} /+79 \mathrm{C}$ (35.2\%) and $+46 \mathrm{G} /+79 \mathrm{G}(23.1 \%)$. The response to salbutamol and asthma severity were compared between carriers of these allele combinations. We found no statistically

Table 2. Comparison of response to salbutamol, severity of the disease and clinical characteristics between carriers of different ADRB2 genotypes.

\begin{tabular}{|c|c|c|c|c|}
\hline$+46 \mathrm{~A}>\mathrm{G}$ & AA & GA & GG & $p$ Value \\
\hline dFEV1 $(\%)($ mean \pm SD) & $9.4 \pm 6.2$ & $10.4 \pm 5.8$ & $14.4 \pm 6.1$ & 0.044 \\
\hline $\begin{array}{l}\text { Asthma severity: } n(\%) \\
\text { mild } \\
\text { moderate } \\
\text { severe }\end{array}$ & $\begin{array}{l}1(4.3) \\
8(57.2) \\
4(27.9) \\
\end{array}$ & $\begin{array}{r}10(43.5) \\
3(21.4) \\
6(35.3) \\
\end{array}$ & $\begin{array}{r}12(52.2) \\
3(21.4) \\
7(41.2) \\
\end{array}$ & 0.010 \\
\hline Atopic dermatitis: $n(\%)$ & $12(27.9)$ & $13(30.2)$ & $18(41.9)$ & 0.244 \\
\hline Eosinophils in peripheral blood (\%) (mean \pm SD) & $6.0 \pm 2.5$ & $6.3 \pm 1.7$ & $6.4 \pm 2.3$ & 0.600 \\
\hline Serum IgE $(\mathrm{IU} / \mathrm{mL})($ mean $\pm \mathrm{SD})$ & $152.4 \pm 47.5$ & $128.0 \pm 53.3$ & $148.9 \pm 49.9$ & 0.440 \\
\hline
\end{tabular}

\begin{tabular}{|c|c|c|c|c|}
\hline$+79 \mathrm{C}>\mathrm{G}$ & $\mathbf{C C}$ & CG & GG & $p$ Value \\
\hline dFEV1 (\%) (mean \pm SD) & $11.6 \pm 5.9$ & $11.7 \pm 7.2$ & $13.2 \pm 7.5$ & 0.955 \\
\hline $\begin{array}{l}\text { Asthma severity: } n(\%) \\
\text { mild } \\
\text { moderate } \\
\text { severe }\end{array}$ & $\begin{array}{l}12(52.2) \\
12(85.7) \\
10(58.8)\end{array}$ & $\begin{array}{l}8(34.8) \\
2(14.3) \\
5(29.4)\end{array}$ & $\begin{array}{l}3(13.0) \\
0(0.0) \\
2(11.8)\end{array}$ & 0.316 \\
\hline Atopic dermatitis: $n(\%)$ & $26(60.5)$ & $13(30.2)$ & $4(9.3)$ & 0.716 \\
\hline Eosinophils in peripheral blood (\%) (mean \pm SD) & $5.9 \pm 1.9$ & $7.1 \pm 1.9$ & $6.2 \pm 3.4$ & 0.089 \\
\hline Serum $\operatorname{IgE}(\mathrm{IU} / \mathrm{mL})($ mean $\pm \mathrm{SD})$ & $141.2 \pm 45.9$ & $134.4 \pm 64.7$ & $172.8 \pm 42.4$ & 0.543 \\
\hline
\end{tabular}

dFEV1: change in forced expiratory volume in the first second after administration of salbutamol; SD: standard deviation. 
significant difference in severity of asthma. In the group of children with the $+46 \mathrm{~A}>\mathrm{G}$ polymorphism and severe asthma, $41.2 \%$ of cases were carriers of the $+46 \mathrm{GG}$ genotype that is associated with the best bronchodilator response. In patients with the $+46 \mathrm{~A} /+79 \mathrm{C}$ combination, the response to salbutamol was significantly worse than in patients with the other two allele combinations (dFEV1 9.4 \pm 6.2 vs. 14.4 $\pm 6.1 \%, p=0.026$ ). There was no significant difference in response of the homozygous and heterozygous carriers of the $+46 \mathrm{~A}$ allele.

\section{DISCUSSION}

The main finding of the study was the association of the $+46 \mathrm{G}$ allele in the ADRB2 gene with a mild form of asthma and better response to salbutamol. The finding that carriers of the ADRB2 $+46 \mathrm{G}$ allele tended to develop a mild form of asthma was in correlation with findings of other studies. In meta-analysis of 28 studies, authors concluded that carriers of the +46 AA genotype had a higher risk of developing severe and nocturnal asthma than carriers of the $+46 \mathrm{GG}$ genotype [14]. On the other hand, an Egyptian study in school-age children with asthma had shown an association of the +46GA genotype with severe asthma [15].

Genetic variation in the $A D R B 2$ gene may have important effect on modulating responses to inhaled $\beta 2$ agonists as the mainstay of asthma therapy. Previous studies have dealt with $+46 \mathrm{~A}>\mathrm{G}$ and $+79 \mathrm{C}>\mathrm{G}$ polymorphisms and their impact on differential agonist-stimulated downregulation of the receptor in transfected cells, including airway smooth muscle cells in humans and which can be associated with a different bronchodilator response to $\beta 2$-agonists [10,11,16-19]. In our study, the presence of the $+46 \mathrm{G}$ allele in the $A D R B 2$ gene was associated with a better response to the bronchodilator effect of inhaled short-acting $\beta 2$-agonists (salbutamol). As noted above, our study showed the association of this +46GG genotype with the phenotype of mild asthma. However, it was noticed in the subgroup of asthmatic children with the $+46 \mathrm{~A}>\mathrm{G}$ polymorphism, the highest percentage of children with severe asthma were the carriers of the $+46 \mathrm{GG}$ genotype. As this genotype was associated with the best response to bronchodilators, we can expect a good clinical response to salbutamol in this subgroup of patients (the severe asthma phenotype who are carriers of the $+46 \mathrm{GG}$ genotype). Monitoring of FEV1 following administration of salbutamol as a response measure for bronchodilator use is the most objective, immediate and most frequently studied pulmonary function parameter in the previous trials [13]. The relationship between ADRB2 genotypes and response to inhaled $\beta 2$-agonists was controversial and discordant findings had been reported. In early studies, authors showed better bronchodilator response in children with the $+46 \mathrm{GG}$ genotype [20]. Later, several studies showed similar results $[21,22]$. The meta-analysis showed a significant association between better therapeutic response to inhaled $\beta 2$-agonist and the $+46 \mathrm{GG}$ genotype [6]. However, a few studies have shown opposite results. Carroll [23] found that children with the +46AA genotype had a more rapid response to inhaled $\beta 2$-agonist. Examining ethnic differences, Choudhry et al. [24] showed better salbutamol response in Mexican children with the +46AA genotype but not in the Puerto Rican ethnic group. The only study conducted in Serbia included adults and showed a better bronchodilator response in carriers of the $+79 \mathrm{C}$ allele in asthmatic patients younger than 50 years [12]. Some larger studies have shown the absence of association of genetic variation of ADRB2 and the response to inhaled $\beta 2$-agonist $[25,26]$. Several reasons may explain the discordant results reported by different authors. The studies were not coherent in terms of age of the subjects and the severity of their illness. Authors had also used different $\beta 2$-agonists and different outcome measures to assess drug responsiveness [27]. Some authors studied the associations of certain haplotypes with therapeutic response to a particular drug and made a conclusion by which different results can be explained by specific combinations of polymorphisms that are most commonly inherited together, rather than individual polymorphisms.

The main limitation of our study was the relatively small number of subjects. On the other hand, we had applied strict criteria for the selection of subjects to avoid the results being influenced by any of the non genetic factors. Children with asthma and other associated illness were not included in the study. The study included children of Serbian ethnicity, although in Serbia there are members of other ethnic communities (e.g., Hungarian, Croatian, Roma). We cannot exclude the possibility that adjacent genes or other polymorphisms within the promoter and coding regions of the $A D R B 2$ gene can contribute to the results. The fact is that there are a multitude of polymorphisms of the $A D R B 2$ gene and a certain set of alleles are more likely to be inherited together as a block. The protective effect of one polymorphism may mask the adverse effect of another polymorphism when inherited together. Hence, association of ADRB2 haplotypes with bronchodilator response may be more relevant than single polymorphisms. For the extrapolation of these results in our population, a larger sample is needed and ethnicity should 
be taken into consideration. The study covered the acute use of short-acting bronchodilators and the results cannot be correlated in light of the effects of their long-term use or, possibly, effects of long-acting bronchodilators.

To conclude, the polymorphism $+46 \mathrm{~A}>\mathrm{G}$ of the $A D R B 2$ gene may be a determinant of asthma severity and the $+46 \mathrm{G}$ allele is a potential predictive marker of response to salbutamol in Serbian children with asthma. The results of our study can help establish future research strategies regarding the role of the $A D R B 2$ gene in asthma and response to therapy, and are of potential use for personalized asthma treatment in children.

\section{ACKNOWLEDGMENTS}

We sincerely thank Dragica Radojkovic (Principal Research Fellow, Laboratory for Molecular Biology, Institute of Molecular Genetics and Genetic Engineering, University of Belgrade, Belgrade, Serbia) for her valuable help with the manuscript.

Declaration of Interest. The authors report no conflicts of interest. The authors alone are responsible for the content and writing of this article.

\section{REFERENCES}

1. Global initiative for asthma. Global strategy for asthma management and prevention, 2016. Available from: www.ginasthma.org.

2. Baren JM, Zorc JJ. Contemporary approach to the emergency department management of pediatric asthma. Emerg Med Clin North Am. 2002; 20(1): 115-138.

3. Martin AC, Zhang G, Rueter K, Geelhoed G, Goldblatt J, Laing I, et al. $\beta 2$-Adrenoceptor polymorphisms predict response to $\beta 2$-agonists in children with acute asthma. J Asthma. 2008; 45(5): 383-388.

4. Barnes KC. Genetic studies of the etiology of asthma. Proc Am Thorac Soc. 2011; 8(4): 143-148.

5. Contopoulos-Ioannidis DG, Manoli EN, Ioannidis JP. Meta-analysis of the association of $\beta 2$-adrenergic receptor polymorphisms with asthma phenotypes. J Allergy Clin Immunol. 2005; 115(5): 963-972.

6. Finkelstein Y, Bournissen FG, Hutson JR, Shannon M. Polymorphism of the ADRB2 gene and response to inhaled $\beta$-agonists in children with asthma: A metaanalysis. J Asthma. 2009; 46(9): 900-905.
7. de Paiva AC, Marson FA, Ribeiro JD, Bertuzzo CS. Asthma: Gln27Glu and Arg16Gly polymorphisms of the $\beta 2$-adrenergic receptor gene as risk factors. Allergy Asthma Clin Immunol. 2014; 10(1): 8.

8. Marson FA, Bertuzzo CS, Ribeiro AF, Ribeiro JD. Polymorphisms in ADRB2 gene can modulate the response to bronchodilators and the severity of cystic fibrosis. BMC Pulm Med. 2012; 12: 50.

9. Chung LP, Waterer G, Thompson PJ. Pharmacogenetics of $\beta 2$ adrenergic receptor gene polymorphisms, long-acting $\beta$-agonists and asthma. Clin Exp Allergy. 2011; 41(3): 312-326.

10. Birbian N, Singh J, Jindal SK, Singla N. Association of $\beta 2$-adrenergic receptor polymorphisms with asthma in a North Indian population. Lung. 2012; 190(5): 497-504.

11. Karam RA, Sabbah NA, Zidan HE, Rahman HM. Association between genetic polymorphisms of $\beta 2$ adre-nergic receptors and nocturnal asthma in Egyptian children. J Investig Allergol Clin Immunol. 2013; 23(4): 262-266.

12. Petrovic-Stanojevic N, Topic A, Nikolic A, Stan-kovic M, Dopudja-Pantic V, Milenkovic B, et al. Polymorphisms of $\beta 2$-adrenergic receptor gene in serbian asthmatic adults: Effects on response to $\beta$-agonists. Mol Diagn Ther. 2014; 18(6): 639-646.

13. American Thoracic Society. Standardization of spirometry, 1994 update. Am J Respir Crit Care Med. 1995; 152(3): 1107-1136.

14. Contopoulos-Ioannidis DG, Manoli EN, Ioannidis JP. Meta-analysis of the association of $\beta 2$-adrenergic receptor polymorphisms with asthma phenotypes. J Allergy Clin Immunol. 2005; 115(5): 963-972.

15. Salama MS, Ashaat NA, Hamad AA. Genetic association between common $\beta$ - 2 adrenoreceptor polymorphism and asthma severity in school-age children. Egyptian J Med Hum Genet. 2012; 12(2): 151-156.

16. Moore PE, Laporte JD, Abraham JH, Schwartzman IN, Yandava CN, Silverman ES, et al. Polymorphism of the $\beta 2$-adrenergic receptor gene and desensitization in human airway smooth muscle. Am J Respir Crit Care Med. 2000; 162(6): 2117-2124.

17. Green SA, Turki J, Bejarano P, Hall IP, Liggett SB. Influence of $\beta 2$-adrenergic receptor genotypes on signal transduction in human airway smooth muscle cells. Am J Respir Cell Mol Biol. 1995; 13(1): 25-33.

18. Asano K, Yamada-Yamasawa W, Kudoh H, Matsuzaki T, Nakajima T, Hakuno H, et al. Association 
between $\beta$-adrenoceptor gene polymorphisms and relative response to $\beta 2$-agonists and anticholinergic drugs in Japanese asthmatic patients. Respirology. 2010; 15(5): 849-854.

19. Fu WP, Zhao ZH, Zhong L, Sun C, Fang LZ, Liu L, et al. Relationship between polymorphisms in the 5 leader cistron, positions 16 and 27 of the adrenergic $\beta 2$ receptor gene and asthma in a Han population from southwest China. Respirology. 2011; 16(8): 1221-1227.

20. Martinez FD, Graves PE, Baldini M, Solomon S, Erickson R. Association between polymorphisms of ADRB2 and response to albuterol in children with and without history of wheezing. J Clin Invest. 1997; 100(12): 3184-3188.

21. Cho SH, Oh SY, Bahn JW, Choi JY, Chang YS, Kim YK, et al. Association between bronchodilating response to SABA and non-synonymous SNP of ADRB2 gene. Clin Exp Allergy. 2005; 35(9): $1162-$ 1167.

22. Salah K, Morsy S, Atta A. Effects of ADRB2 polymorphism on asthma severity and response to salbutamol on Egyptian children. Egypt J Pediatr Allergy Immunol. 2012; 10(2): 81-86.
23. Carroll CL, Stoltz P, Schramm CM, Zucker AR. ADRB2 polymorphisms affect response to treatment in children with severe asthma exacerbations. Chest. 2009; 135(5): 1186-1192.

24. Choudhry S, Ung N, Avila PC, Ziv E, Nazario S, Casal J. Pharmacogenetic differences in response to albuterol between Puerto Ricans and Mexicans with asthma. Am J Respir Crit Care Med. 2005; 171(6): 563-570.

25. Szczepankiewicz A, Breborowicz A, Sobkowiak P, Kramer L, Popiel A. Role of ADRB2 gene polymorphism in asthma and response to $\beta 2$-agonists in Polish children. J Appl Genet. 2009; 50(3): 275-281.

26. Isaza C, Sepúlveda-Arias JC, Agudelo BI, Arciniegas W, Henao J, Porras GL, et al. ADRB2 polymorphisms in asthmatic and non-asthmatic school children from Colombia and their relationship to treatment response. Pediatr Pulmonol. 2012; 47(9): 848-855.

27. Turner S, Francis B, Vijverberg S, Pino-Yanes M, Maitland-van der Zee AH, Basu K, et al. Childhood asthma exacerbations and the $\operatorname{Arg} 16 \beta 2$-receptor polymorphism: A meta-analysis stratified by treatment. J Allergy Clin Immunol. 2016; 138(1): 107-113. 